\title{
定比カチオン $\mathrm{Bi}_{2} \mathrm{Sr}_{2} \mathrm{CuO}_{\delta}$ の常圧下での合成と変調構造
}

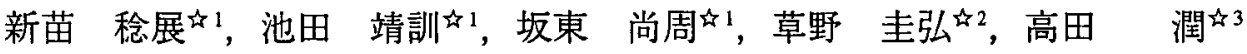

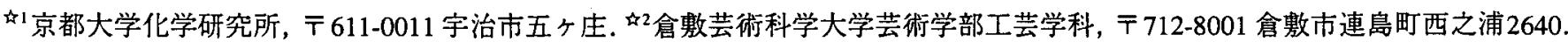 \\ $4^{3}$ 岡山大学工学部精密応用化学科, $\bar{\top}$ 700-8530 岡山市津島中 3-1-1.
}

\section{The Modulation and Synthesis for $\mathrm{Bi}_{2} \mathrm{Sr}_{2} \mathrm{CuO}_{\delta}$ under Ambient Oxygen Partial Pressure}

\author{
Toshinobu Niinae ${ }^{\not 1}$, Yasunori Ikeda ${ }^{\not 1}$, Yoshichika Bando ${ }^{\hbar^{1}}$, Yoshihiro Kusano ${ }^{2^{2}}$ and Jun Takada ${ }^{3}$ \\ ${ }^{1}$ Institute for Chemical Research, Kyoto University, Uji 611-0011. ‘2Department of Applied art, College of the Arts, Kurashiki University \\ of Science and the Arts, 2640 Nishinoura Tsurajima-cho, Kurasiki 712-8001. ${ }^{3}$ Department of Applied Chemistry, Faculty of Engineering, \\ Okayama University, 3-1-1 Tsushima-naka, Okayama 700-8530.
}

Received April 16, 1998

\section{SYNOPSIS}

The cation stoichiometric $\mathrm{Bi}_{2} \mathrm{Sr}_{2} \mathrm{CuO}_{\delta}$ was successfully obtained by solid state reaction under ambient oxygen pressures $\left(\mathrm{Po}_{2}=0.2,1 \mathrm{~atm}\right)$. The modulation period as estimated by means of $\mathrm{X}$-ray powder diffraction was $\lambda \cong 4.7 \mathrm{~b}$ for $\mathrm{Bi}_{2} \mathrm{Sr}_{2} \mathrm{CuO}_{\delta}$ synthesized under $\mathrm{Po}_{2}=1$ atm, which is shorter than that for $\mathrm{Bi}_{2.125} \mathrm{Sr}_{1.875} \mathrm{CuO}_{z}(\lambda \cong 15 \mathrm{~b}) . \mathrm{The} \mathrm{Bi}_{2} \mathrm{Sr}_{2} \mathrm{CuO}_{\delta}$ synthesized under $\mathrm{Po}_{2}=1$ atm showed metallic conductivity down to $2 \mathrm{~K}$, whereas it done under $\mathrm{Po}_{2}=0.2$ atm showed superconductivity with $\mathrm{Tc} \approx 8 \mathrm{~K}$. By annealing in $\mathrm{Ar}, \mathrm{Tc}$ was raised up to $16 \mathrm{~K}$. At the same time, it was newly found that the modulation is disproportionate into two types with $\lambda \cong 4.7 \mathrm{~b}$ and $\lambda \cong 5.5 \mathrm{~b}$.

KEY WORDS

The cation stoichiometric $\mathrm{Bi}-2201$, monophasic $\mathrm{Bi}_{2} \mathrm{Sr}_{2} \mathrm{CuO}_{\delta}$, superconductor, a new modulation mode

\section{1 緒 言}

Bi-2201 相は他のBi系超伝導体の基本構造を持って㧈り，各 種元素を置換する事により，金属的伝導-超伝導一半導体的伝 導”に変化するなど，基礔的な研究に対し，興味を持たれ世界 中で広く研究されている. Bi-2201 相はBi と Srの置換による固 溶域を持っている。我々は以前 $840^{\circ} \mathrm{C}$ 空気中で $\mathrm{BiO}_{1.5}-\mathrm{SrO}-\mathrm{CuO}$ 系状態図を作製し，その固溶域を $\mathrm{Bi}_{2+x} \mathrm{Sr}_{2-\mathrm{x}} \mathrm{Cu}_{1+y} \mathrm{O}_{z}(0.1<\mathrm{x}<0.6$, $0 \leq y<x / 2)$ と決定した ${ }^{2)}$. 一方, Saggio らは, $800^{\circ} \mathrm{C}$ 空気中で検討 しその固溶域を $0.12 \leq x \leq 0.2$ としている ${ }^{3)}$. Roth らは $880^{\circ} \mathrm{C}$ 空気 中で $0.2 \leq x \leq 0.35$ としている4. 我々および Saggioらの結果から は固溶体中, 最もBi-poorな組成をもつBi-2201相で, 超伝導が 観測されている。しかしながら，このように報告者により Bipoor 側における固溶域が異なっていることは，最もBi-poorな $\mathrm{x}=0.12$ 組成を持つ良質なバルク超伝導体の作製は困難であるこ

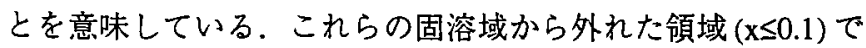
は，いずれの報告でもBi-2201 と組成が非常に近く構造も良く 似た絶縁相が共存する.この構造は $\mathrm{Bi}-2201$ 相と比較して $\mathrm{CuO}_{2}$ 面が剪断されているシアー構造を取っている゙．Bi-2201相にお ける超伝導の本質を理解する上で良質な試料は必要不可欠であ り，そのためには，まずこの絶縁体相と Bi-2201 相の関係を正
確に理解することが必要である。一方で, 高酸素圧下で Bi2201 固溶域が $\mathrm{x}=0$ まで広がることが報告されている. L.F. Schneemeyer らは, $850^{\circ} \mathrm{C}$ で酸素分圧 $20 \mathrm{~atm}$ で $\mathrm{x}=0.05$ の試料を 合成している6. M.Kato らは $830^{\circ} \mathrm{C}$ で酸素分圧 $30 \mathrm{~atm}$ で $\mathrm{x}=0$ の 試料を合成している7). 最近, 我々はこの系に対して低温での 熱処理過程の重要性に注目して状態図を作製している.これら の結果, 低温でしかも非常に安定温度域の狭い化合物の生成分解反応が $840^{\circ} \mathrm{C}$ 付近での相関係に著しく影響を及ほすすことを 明らかにした.これらの研究の過程に扔いて我々は定比カチオ ン $\mathrm{Bi}_{2} \mathrm{Sr}_{2} \mathrm{CuO}_{\delta}$ の常圧での単相試料の合成に成功した. そこで本 研究では，ます，定比カチオン $\mathrm{Bi}_{2} \mathrm{Sr}_{2} \mathrm{CuO}_{5}$ の安定領域を決定し， さらに変調構造に対して今までの報告とは異なる新しい知見が 得られたので報告する。

\section{2 試料および実験方法}

原料粉として $\mathrm{Bi}_{2} \mathrm{O}_{3}, \mathrm{SrCO}_{3}, \mathrm{CuO}$ (それぞれ $99.9 \%$ 以上) を用 いて，通常の固相反応法で試料を合成した。これらの試薬を $\mathrm{Bi}: \mathrm{Sr}: \mathrm{Cu}=2: 2: 1$ の組成に秤量し，瑪瑙乳鉢中で十分混合した後， ペレット状に加圧成形し $600^{\circ} \mathrm{C} \sim 840^{\circ} \mathrm{C} て ゙ 20^{\circ} \mathrm{C} \sim 30^{\circ} \mathrm{C}$ ずつ段階 的にそれぞれ $20 \mathrm{~h}$ 熱処理した。各熱処理間で粉砕・混合・成形 
を繰り返し行った。これらの熱処理を酸素気流中 (1atm), 大 気中, $\mathrm{Ar}$ 気流中でそれぞれ行った。 このようにして得られた

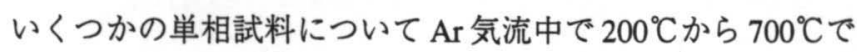
$12 \mathrm{~h} \sim 240 \mathrm{~h}$ アニーリングを行った. 試料の同定にはグラファイ トモノクロメーターを使用した粉末 X 線回折 (XRD, Cu-K $\alpha$, Rigaku RU-200)を用いて 40kV, 180mA で行った. 酸素量の変 化は示差熱重量分析 (TG-DTA, MAC SCIENCE 社製 TGDTA 2000)を用いた。 また, TEM (TOPCON EMO02B)により電子線 回折実験およびSQUID (QuantumDesign 社製, MPMSR2)によ る带磁率測定, 直流 4 端子法による電気抵抗測定を行った。

\section{3 結果と考察}

3.1 合成と安定性

$\mathrm{BiO}_{1.5}-\mathrm{SrO}-\mathrm{CuO}$ 系で, $720^{\circ} \mathrm{C} \sim 800^{\circ} \mathrm{C}$ の比較的低温領域では 温度に対し非常に不安定な相があるため特に各過程の熱処理 間の温度幅を出来るだけ狭くとり慎重に行うことが重要であ る. そこで, まず定比カチオン $\mathrm{Bi}_{2} \mathrm{Sr}_{2} \mathrm{CuO}_{\delta}$ を得るため出発原

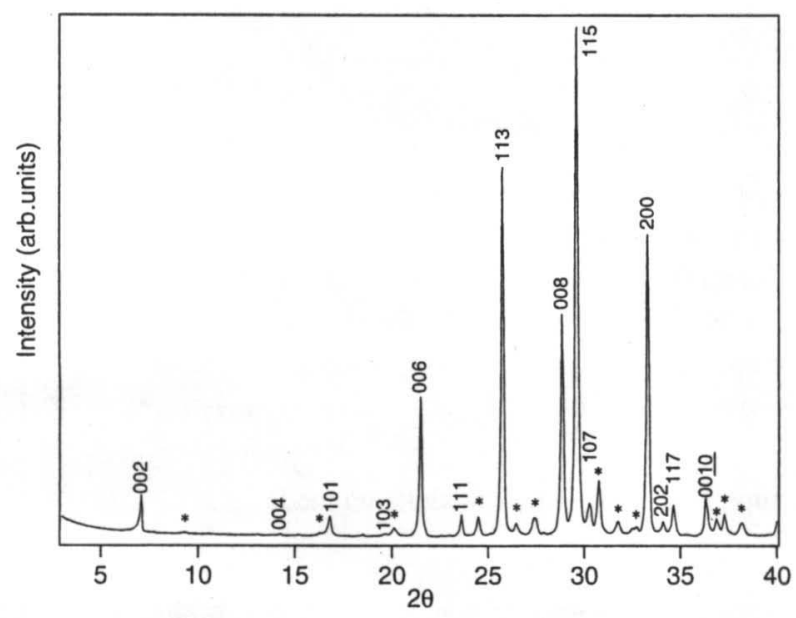

Fig.1 XRD pattern for $\mathrm{Bi}_{2} \mathrm{Sr}_{2} \mathrm{CuO}_{\delta}$ phase synthesized at $800^{\circ} \mathrm{C}$ for $20 \mathrm{~h}$ in $\mathrm{O}_{2}$ flow. The stars indicated modulation reflection peaks.

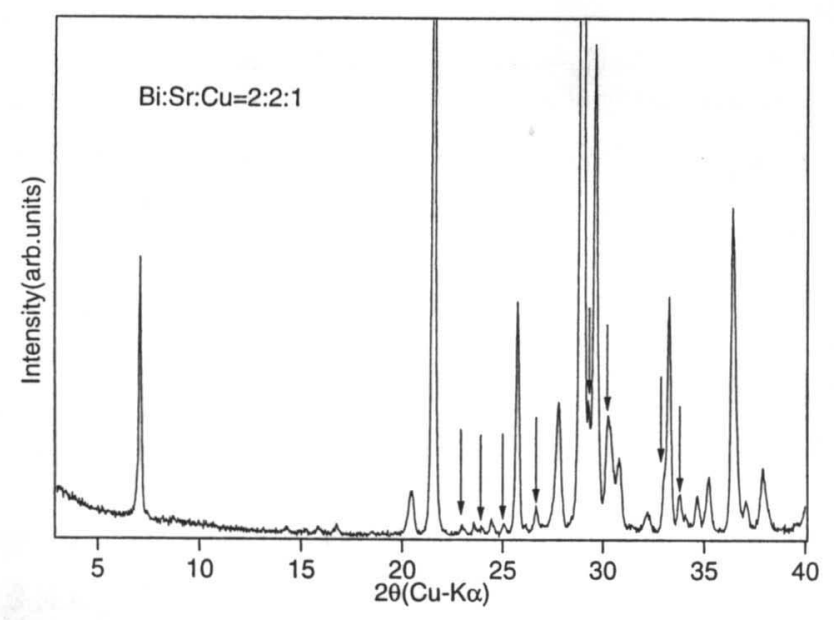

Fig.2 XRD pattern for the sample heated at $820^{\circ} \mathrm{C}$ for $20 \mathrm{~h}$ after heating at $800^{\circ} \mathrm{C}$ for $20 \mathrm{~h}$ in $\mathrm{O}_{2}$ flow. $\downarrow: \mathrm{Bi}_{17} \mathrm{Sr}_{16} \mathrm{Cu}_{7} \mathrm{O}_{\delta}$
料を酸素気流中で $720^{\circ} \mathrm{C} \sim 800^{\circ} \mathrm{C} て ゙ 20^{\circ} \mathrm{C} \sim 30^{\circ} \mathrm{C}$ ずつ段階的に熱 処理した. 熱処理時間は total で 80h 費やした. Fig.1に酸素気

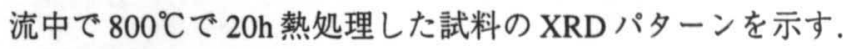
比較的安定である $\mathrm{SrCO}_{3}, \mathrm{CuO}$ などの原料粉が存在せず, $\mathrm{Bi}-$ $\mathrm{Sr}-\mathrm{O}$ 系化合物, $\mathrm{Bi}_{17} \mathrm{Sr}_{16} \mathrm{Cu}_{7} \mathrm{O}_{2}, \mathrm{Sr}_{14} \mathrm{Cu}_{24} \mathrm{O}_{41}$ などの不純物相も含ま れていない.このBi-2201の格子定数は $\mathrm{a} \sim 5.361 \AA, \mathrm{c} \sim 24.65 \AA$ であり, 最も Bi-poorな $\mathrm{x}=0.125$ の試料の格子定数 ( $\mathrm{a} \sim 5.385 \AA$, $\mathrm{c} \sim 24.63 \AA$ ) と比較すると, $\mathrm{a}$ 軸は長く $\mathrm{c}$ 軸は短いが, その変化 は非常に僅かであり組成の確定は格子定数だけでは判断が難 しい. また, $\mathrm{Bi}_{2+x} \mathrm{Sr}_{2-x} \mathrm{CuO}_{2}$ 固溶体は変調構造を持っており, 変 調周期は $\mathrm{x}$ により系統的に変化する ${ }^{2,8}$. この変調周期の変化 はXRDでも観測される. Fig.1に示したBi-2201の変調ピーク の位置は $\mathrm{x}=0.125$ の位置とは異なり,このことから, Fig. 1 中 のBi-2201 は，0.1<x<0.6の組成ではないことがわかった。 こ の試料を $820^{\circ} \mathrm{C}-20 \mathrm{~h}$ 熱処理すると Fig.2に示したように

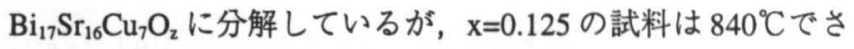
え安定であることから, 両者は熱的安定性においても異なる。 これらのことから我々はこの試料が定比カチオン $\mathrm{Bi}_{2} \mathrm{Sr}_{2} \mathrm{CuO}_{\delta}$
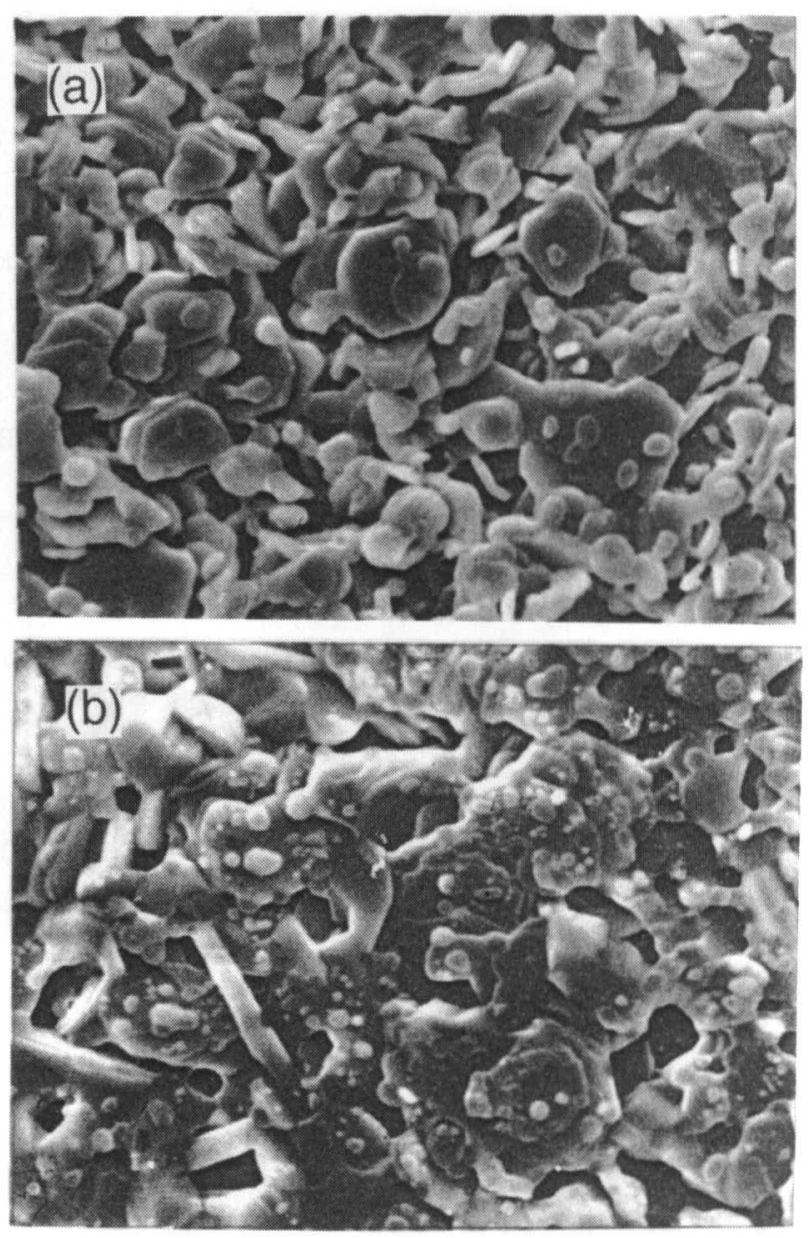

$10 \mu \mathrm{m}$

Fig.3 SEM images of $\mathrm{Bi}_{2} \mathrm{Sr}_{2} \mathrm{CuO}_{\delta}$ phase (a) and the same sample heated at $820^{\circ} \mathrm{C}$ for $20 \mathrm{~h}$ in $\mathrm{O}_{2}$ flow (b). 
単相試料であることを判断した，次にこれらの試料の粒子形 態を観察した. Fig.3に Fig.1 と Fig.2の試料の表面のSEM観察 結果を示す. $800^{\circ} \mathrm{C}$ の試料は数 $\mu \mathrm{m}$ の板状粒子で構成され，定 比カチオン $\mathrm{Bi}_{2} \mathrm{Sr}_{2} \mathrm{CuO}_{\delta}$ が今までの固溶体同様の粒子形態を 持っていることがわかる. $820^{\circ} \mathrm{C}$ で熱処理した試料は, この板 状粒子の表面に〜0.5 $\mu \mathrm{m}$ の粒子が析出している.XRDの結果 から,この数 $\mu \mathrm{m}$ の粒子は $\mathrm{Bi}_{17} \mathrm{Sr}_{16} \mathrm{Cu}_{7} \mathrm{O}_{2}(17.16 .7)$ と考えられる.

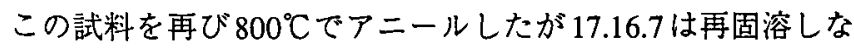
い.このことから定比カチオン $\mathrm{Bi}_{2} \mathrm{Sr}_{2} \mathrm{CuO}_{\delta}$ を得るには高温安 定相である $\mathrm{Bi}_{17} \mathrm{Sr}_{15} \mathrm{Cu}_{7} \mathrm{O}_{2}$ 相の生成温度以下で熱処理すること が重要であることが明らかで，この点を十分踏まえて空気中 での合成を次に試みた。 まず，Fig.4に示すように酸素中と同 様に $720^{\circ} \mathrm{C}$ から約 $30^{\circ} \mathrm{C}$ おにに段階的に熱处理を行った. $720^{\circ} \mathrm{C}$ ではBi-2201 の他，原料粉である $\mathrm{SrCO}_{3}, \mathrm{CuO}$ が残存し， $\mathrm{Bi}_{2} \mathrm{SrO}_{2}, \mathrm{BiSrO}_{2.5}$ ，が不純物として生成している， $750^{\circ} \mathrm{C}$ に昇温 すると，新たに $\mathrm{Bi}_{2} \mathrm{Sr}_{3} \mathrm{O}_{z}$ が生成する。さらに $780^{\circ} \mathrm{Cでは} \mathrm{BiSrO}_{2.5}$, $\mathrm{Bi}_{2} \mathrm{Sr}_{3} \mathrm{O}_{2}$ は残存したまま $\mathrm{Bi}_{17} \mathrm{Sr}_{16} \mathrm{Cu}_{7} \mathrm{O}_{2}$ が僅かに生成する。 そこ で我々は, $780^{\circ} \mathrm{C}$ 以下の温度で熱処理することに決定した。 ま

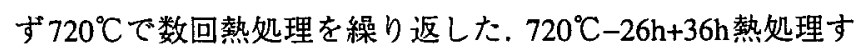
ると $\mathrm{SrCO}_{3}, \mathrm{Bi}_{2} \mathrm{SrO}_{2}$ が消失し， Bi-2201, $\mathrm{BiSrO}_{2.5}, \mathrm{CuO}$ となる. この不純物相の種類から共存する Bi-2201 は定比カチオン 2201 であることが予想され，この混合粉をさらに $80 \mathrm{~h}$ 熱処理 すると Bi-2201 単相試料となった.この試量を $730^{\circ} \mathrm{C} て ゙ 20 \mathrm{~h}$ 熱 処理したが, 単相のまま変化がなかった。 そのXRDパターン

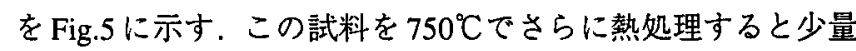
の $\mathrm{Bi}_{17} \mathrm{Sr}_{16} \mathrm{Cu}_{7} \mathrm{O}_{2}$ が生成した。これらの結果から定比カチオン $\mathrm{Bi}_{2} \mathrm{Sr}_{2} \mathrm{CuO}_{\delta}$ は酸素圧 $1 \mathrm{~atm}, 0.2 \mathrm{~atm}$ 下でそれぞれ, $800^{\circ} \mathrm{C}, 730^{\circ} \mathrm{C}$ まで安定であることが明らかとなった。また，酸素分圧が $\mathrm{Po}_{2}<0.2 \mathrm{~atm}$ でも温度を下げることにより合成可能であること が予想できる.従って次にAr気流中での合成を試みた。熱処

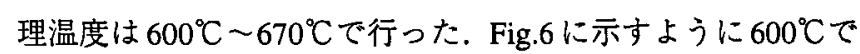

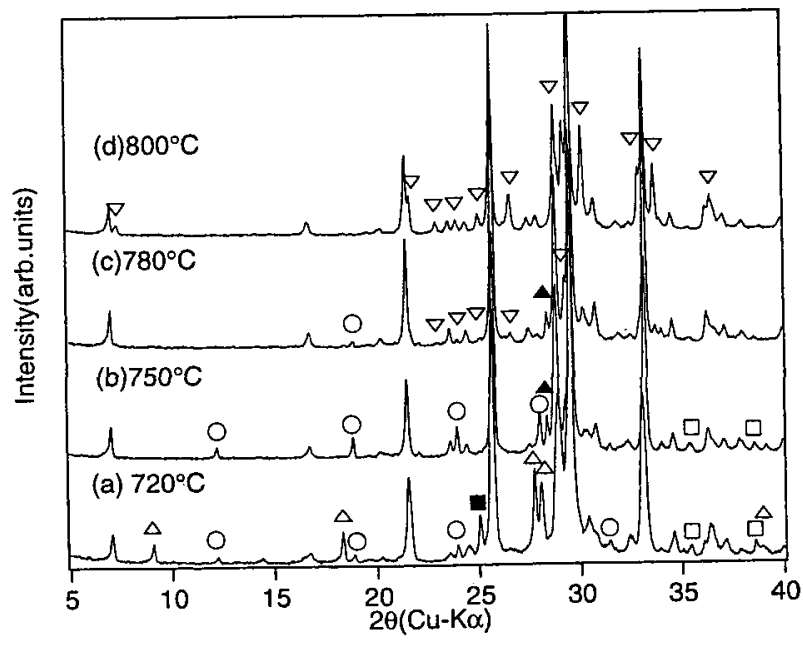

Fig.4 XRD pattern for the samples with ratio of $\mathrm{Bi}: \mathrm{Sr}: \mathrm{Cu}=2: 2: 1$ heated at various temperature for $26 \mathrm{~h}$ in air. $\triangle: \mathrm{Bi}_{2} \mathrm{SrO}_{2}$, $: \mathrm{SrCO}_{3}, \square: \mathrm{CuO}, \bigcirc: \mathrm{BiSrO}_{2.5}, \triangle: \mathrm{Bi}_{2} \mathrm{Sr}_{3} \mathrm{O}_{2}, \nabla:$ $\mathrm{Bi}_{17} \mathrm{Sr}_{16} \mathrm{Cu}_{7} \mathrm{O}_{\delta}$
加熱することにより Bi-2201 相はすでに生成し， $650^{\circ} \mathrm{C} て ゙ 100 \mathrm{~h}$ 熱処理することにより $\mathrm{SrCO}_{3}$ は完全に分解する。しかし、こ の時点でまだ, $\mathrm{BiSrO}_{2 s}, \mathrm{Bi}_{1-x} \mathrm{Sr}_{\mathrm{x}} \mathrm{O}_{2}(0.2<\mathrm{x}<0.3)$ と $\mathrm{CuO}$ が不純物 として存在する。ささらに $660^{\circ} \mathrm{C} て ゙$ 加熱することにより， $\mathrm{Bi}_{1-\mathrm{x}}$ $\mathrm{Sr}_{x} \mathrm{O}_{z}(0.2<\mathrm{x}<0.3)$ は分解するが, $\mathrm{BiSrO}_{2.5}$ は増加する。 そして $670^{\circ} \mathrm{C}$ で $\mathrm{Bi}_{17} \mathrm{Sr}_{16} \mathrm{Cu}_{7} \mathrm{O}_{z}$ が生成する.そこで， $660^{\circ} \mathrm{C}$ で加熱した 試料を再び $660^{\circ} \mathrm{C} て ゙$ 加熱しても不純物の隇少は認められず, 結 局, 単相試料は得られなかった。このことは非常に低い温度 での焼成となるため固相間での反応は非常におそく，より長 時間の熱処理が必要であるため合成が困難であるのか，ある いは定比カチオン $\mathrm{Bi}_{2} \mathrm{Sr}_{2} \mathrm{CuO}_{\delta}$ の構造をとるには過剩酸素が必 要で, Ar中ではその過㮃酸素の供給源がないためか現段階で は判断できない。一方酸素中で合成した試料(Fig.1)をAr気流 中 $650^{\circ} \mathrm{C} て ゙ 20 \mathrm{~h}$ アニールすると，不純物の生成は認められず，

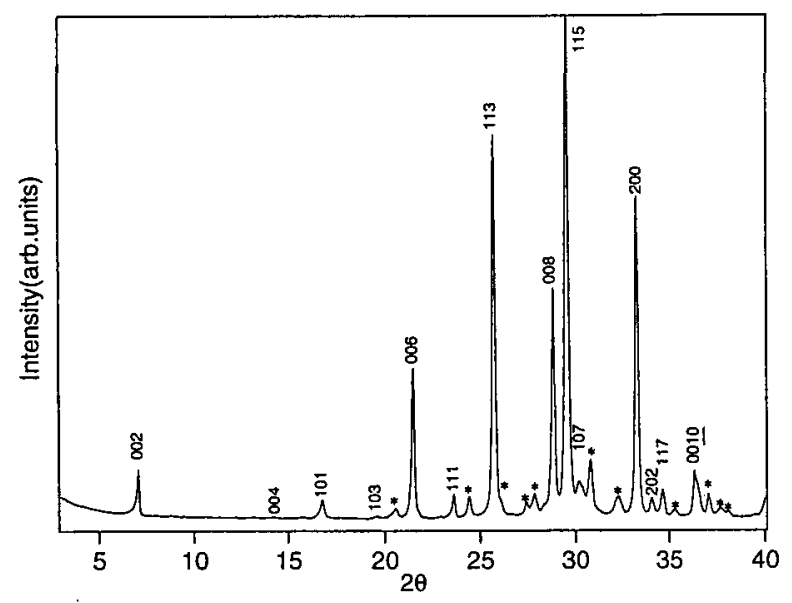

Fig.5 XRD pattern for $\mathrm{Bi}_{2} \mathrm{Sr}_{2} \mathrm{CuO}_{\delta}$ phase synthesized at $730^{\circ} \mathrm{C}$ for $20 \mathrm{~h}$ in air after heated at $720^{\circ} \mathrm{C}$ for $142 \mathrm{~h}$ in air. The stars indicated modulation reflection peaks.

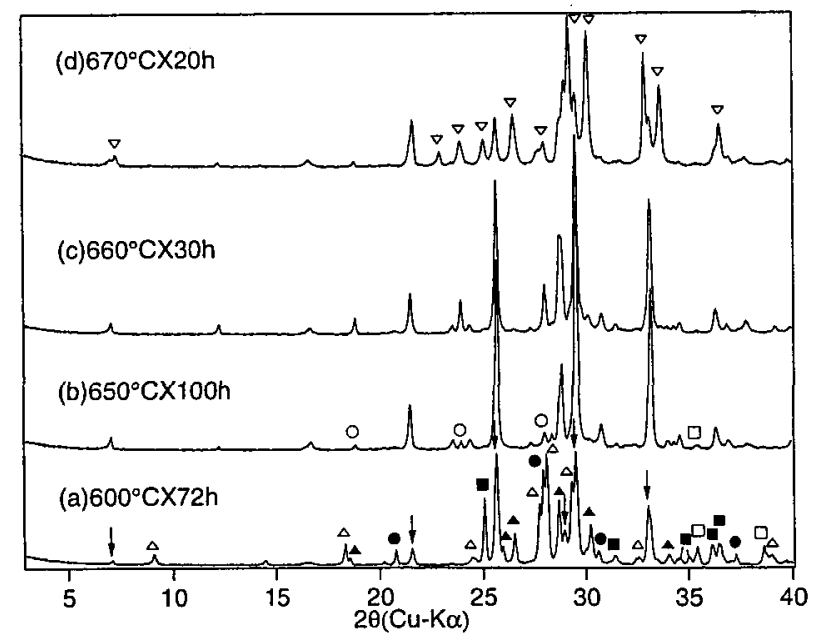

Fig.6 XRD pattern for the sample with ratio of $\mathrm{Bi}: \mathrm{Sr}: \mathrm{Cu}=2: 2: 1$ heated at various temperature in Ar flow. $\downarrow: 2201 \triangle$ : $\mathrm{Bi}_{2} \mathrm{SrO}_{2}, \mathbf{\square}: \mathrm{SrCO}_{3}, \square: \mathrm{CuO}, \mathrm{Bi}_{2} \mathrm{CuO}_{4}, \Delta: \mathrm{Bi}_{\mathrm{l}-\mathrm{x}} \mathrm{Sr}_{\mathrm{x}} \mathrm{O}_{2}$ $(0.2<\mathrm{x}<0.3), \mathrm{O}: \mathrm{BiSrO}_{2.5}, \nabla: \mathrm{Bi}_{17} \mathrm{Sr}_{16} \mathrm{Cu}_{7} \mathrm{O}_{\delta}$ 
$700^{\circ} \mathrm{C} て ゙ 20 \mathrm{~h}$ アニールすると不純物が生成することから，Ar中

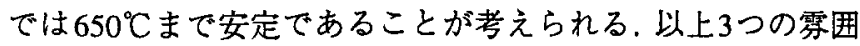
気下での検討から, 定比カチオンBi-2201は酸素圧の增加に伴 い，温度も単調に增加することが明らかとなり，今まで不明 瞭であった定比カチオンBi-2201相の安定領域が確立できた.

\section{2 変調構造}

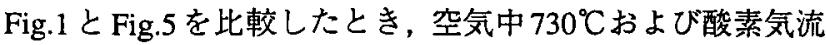
中 $800^{\circ} \mathrm{C} て ゙$ 合成した定比カチオンBi-2201の変調構造に起因し ているピークが異なっている.特に空気中で合成したBi-2201 の(006)-1 扔よび(008)-1 面に起因すると思われるピークが2つ に分離している.この空気中で合成した試料を $800^{\circ} \mathrm{C}$ 酸素中で

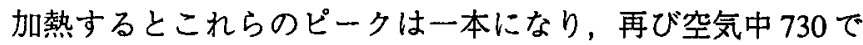

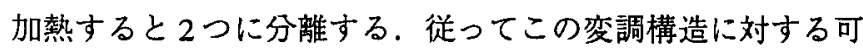
逆的な変化はBi-2201の酸素量に深く関係していると考えられ る。これらの関係をより明確にするため，我々は，酸素中で 合成した試料を様々な温度一時間で $\mathrm{Ar}$ 気流中でアニールし た。これらのXRDパターンを Fig.7に示す. 最も顕著な変化 は (006)-1および (008)-1 に対するピークが高角側にシフトし， 更に2つに分離していることであり，その分蜼したピークの 強度比がアニール温度により変化している． $300^{\circ} \mathrm{C} て ゙ 18 \mathrm{~h} ア$ ニールした試料では(008)-1 に起因すると思われる2つのピー

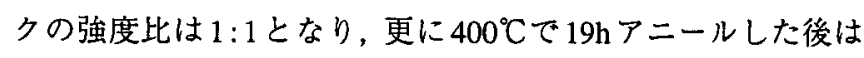
1 (低角側のピーク): 3 (高角側のピーク)となる。しかしな

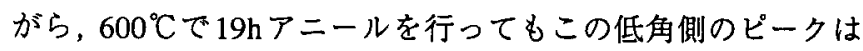
消失せず，そのピークは単一にはならない。さらに $660^{\circ} \mathrm{Cで}$ 50h アニールしたがこのピークは, 分離したままで，しかも試 料中にごく僅かな $\mathrm{Bi}_{17} \mathrm{Sr}_{16} \mathrm{Cu}_{7} \mathrm{O}_{2}$ が生成する。 また，これらの アニール前後でのBi-2201の基本反射に対する格子定数および 半值幅はほとんど変化はなかった。

これらのピークの分離はアニールする以前の試料に根本的 な原因が存在する可能性がある。つまり，酸素気流中で作成

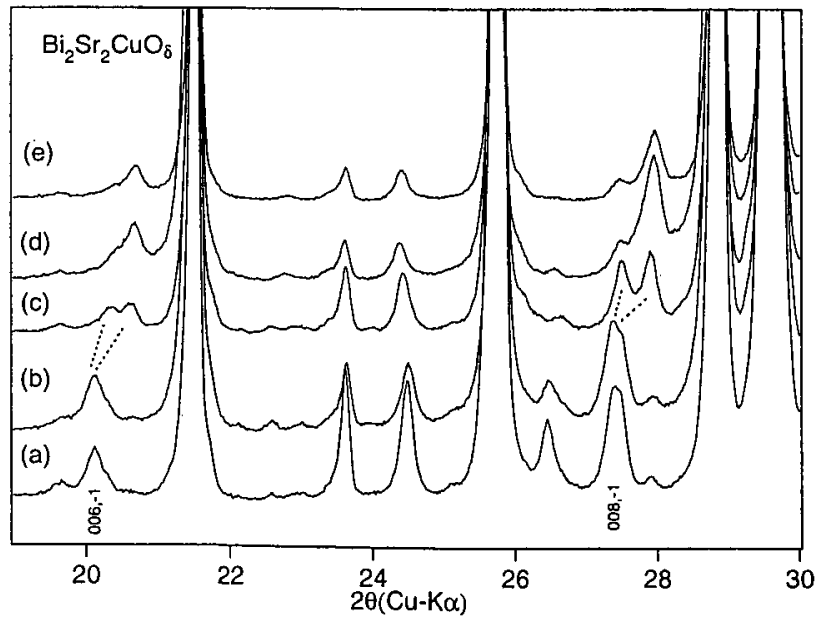

Fig.7 The change of the superlattice diffraction peaks by annealing in Ar flow. (a) as prepared $\left(800^{\circ} \mathrm{C}\right.$ in $\mathrm{O}_{2}$ ), (b) $200^{\circ} \mathrm{C}$ for $24 \mathrm{~h}$, (c) $300^{\circ} \mathrm{C}$ for $18 \mathrm{~h}$, (d) $400^{\circ} \mathrm{C}$ for $19 \mathrm{~h}$, (e) $600^{\circ} \mathrm{C}$ for $19 \mathrm{~h}$
した試料はXRDからは単相であるが, 合成温度が比較的低い ため原子のディスオーダーが存在し，Arアニールした際の変調 に影響する事が考えられる。そこで，より高温である $840^{\circ} \mathrm{C}$, $\mathrm{Po}_{2}=30 \mathrm{~atm}$ で HIP 処理した後， $600^{\circ} \mathrm{C} て ゙ 70 \mathrm{hAr}$ 気流中でアニー ルした. Fig.8に示したようにHIP処理した試料も酸素気流中 で作成した試料と同様に変調ピークは分離する。この結果か ら，作製時の温度は影響していないことがわかる。

これらの現象をより直接的に理解するため,酸素気流中800 ${ }^{\circ} \mathrm{C}$ で作製した試料とその後 $600^{\circ} \mathrm{C}-19 \mathrm{hAr}$ 気流中でアニールし た試料についてTEM観察を行った。 その結果, 驚くべきこと に,これら2つの試料からは同一のEDパターンしか観測され なかった。これらの変調周期は今まで報告されてきた $\mathrm{Bi}_{2+x}$

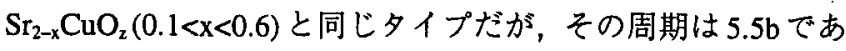
り最も長い. しかし， as-preparedの試料に対し，同一の変調 タイプと仮定してXRDから計算すると鼻その周期は $4.7 \mathrm{~b}$ とな

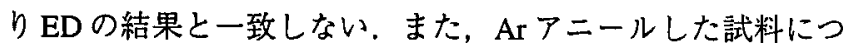
いても，XRDで認められた複数の変調周期は観測されなかっ た.この矛盾は，㧍そらく TEM観察の際, 真空中で電子線を 照射することにより構造が変化していることから起こってい るものと考えられる，従って現在のところ，酸素中で合成し たBi-2201の変調構造は残念ながら不明であり，変調構造の分 離も直接には観測することは出来なかった.

次に，これらの変調構造の変化が過剩酸素と深く関倸して いるものと考え，TG-DTAを用いて酸素中で合成した試料の 重量変化から酸素量を見積もることを試みた。しかしながら $\mathrm{Ar}$ ガス気流下で $650^{\circ} \mathrm{C}$ まで測定したが重量変化はなかった. 今回の我々の結果は, L.F.Schneemeyer らの報告的と一致して いる. 彼らは, $850^{\circ} \mathrm{C} て ゙ 20 \mathrm{~atm}$ で作製した $\mathrm{Bi}_{2.05} \mathrm{Sr}_{1.95} \mathrm{CuO}_{\delta}$ に対 しTG-DTA測定において重量変化は認められなかったと報告 している，おそらく酸素量の変化は非常に僅かであることが

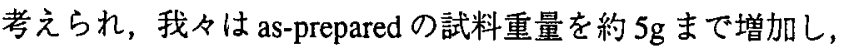

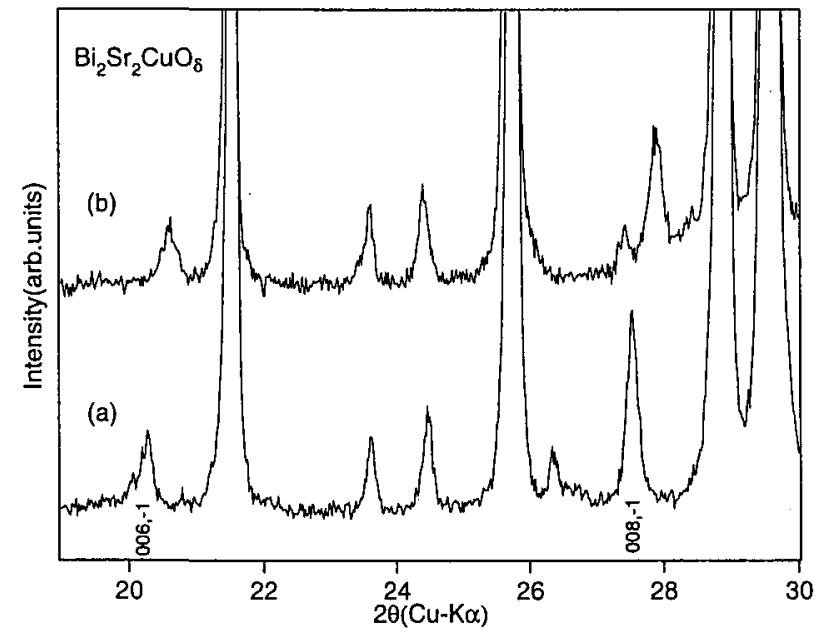

Fig.8 The change of the superlattice diffraction peaks. (a) HIP treatment at $840^{\circ} \mathrm{C} \mathrm{Po}_{2}=30 \mathrm{~atm}$ (b) annealed at $600^{\circ} \mathrm{C}$ in $\mathrm{Ar}$ after HIP treated 


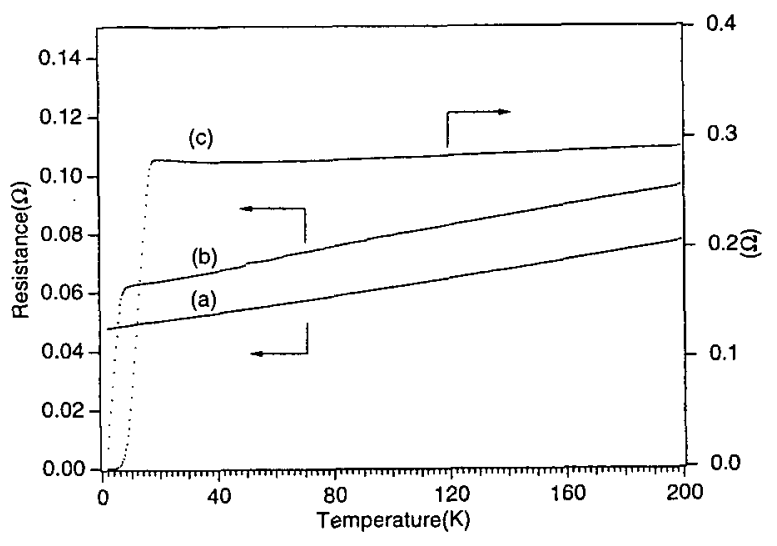

Fig.9 Temperature dependence of resistance for samples of $\mathrm{Bi}_{2} \mathrm{Sr}_{2} \mathrm{CuO}_{\delta}$ prepared at $800^{\circ} \mathrm{C}$ in $\mathrm{O}_{2}\left(\right.$ a), at $730^{\circ} \mathrm{C}$ in air (b), and (c) annealed at $650^{\circ} \mathrm{C}$ in $\mathrm{Ar}(\mathrm{c})$.

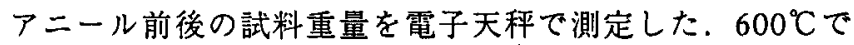
19hAr中でアニールした試料の重量は as-prepared の試料と比 較して $0.05 \%$ の減量が認められた. 従って, 非常に僅かな過㮃 酸素の減量が変調構造の変化をもたらしていると考えられる.

\section{3 物性}

Fig.9に $\mathrm{Bi}_{2} \mathrm{Sr}_{2} \mathrm{CuO}_{\delta}$ について酸素中 $800^{\circ} \mathrm{C} て ゙$ 合成した試料(a) と空気中 $730^{\circ} \mathrm{C} て ゙$ 合成した試料及び(a)の試料を $650^{\circ} \mathrm{C} て ゙ 20 \mathrm{hAr}$ 気流中でアニールした試料の電気抵抗結果を示す. (a)の試料 は $2 \mathrm{~K}$ まで金属的な伝導を示すが，Ar中アニールした試料は 15K で超伝導転移を示す. Fig.10にSQUIDによる帯磁率測定 結果を示したように,アニール温度の增加と共にTcは上昇す る.ただ，超伝導体積分率が小さく Fig.4で示したように 2 種 類の変調構造の typeが共存していることに関係している。う まり，同一粒子内で $2 つ の$ 变調構造の分布が原因となってい ると考えられる。この問題は，高圧合成した $\mathrm{Bi}_{2} \mathrm{Sr}_{2} \mathrm{CuO}_{\delta}$ でも 同椂で, 超伝導体にするためにはAr中で処理しなければなら ず，変調構造の分離は回避できない，従って，現在までのと ころ, 定比カチオン $\mathrm{Bi}_{2} \mathrm{Sr}_{2} \mathrm{CuO}_{\delta}$ の超伝導体は変調構造を含め るとすべて単相にはなっていないと考えられる. 今後, 変調 構造を分離することなく過剩酸素のみ引き抜くことが超伝導 転移がシャープで良質なバルク超伝導体の作製に必要である.

\section{4 結 言}

我々は，定比カチオン $\mathrm{Bi}_{2} \mathrm{Sr}_{2} \mathrm{CuO}_{\delta}$ を常圧で合成し，その安

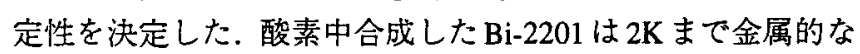
伝導を示すのに対し，不活性なガスのもとでアニールするこ とにより，超伝導を示し，同時に変調 (4.7b) が2 種類の変調構 造 (4.7b 扝よび $5.5 \mathrm{~b}$ ) に分離する。この分離は，非常に僅かな 酸素量の変化で引き起こり, 定比カチオン $\mathrm{Bi}_{2} \mathrm{Sr}_{2} \mathrm{CuO}_{\delta}$ で超伝導 を示す試料は変調も含めると多相になっていると考えられる。

\section{謝 辞}

$\mathrm{Bi}_{2} \mathrm{Sr}_{2} \mathrm{CuO}_{5}$ の HIP 処理をしていただいた, 三重大学工学部

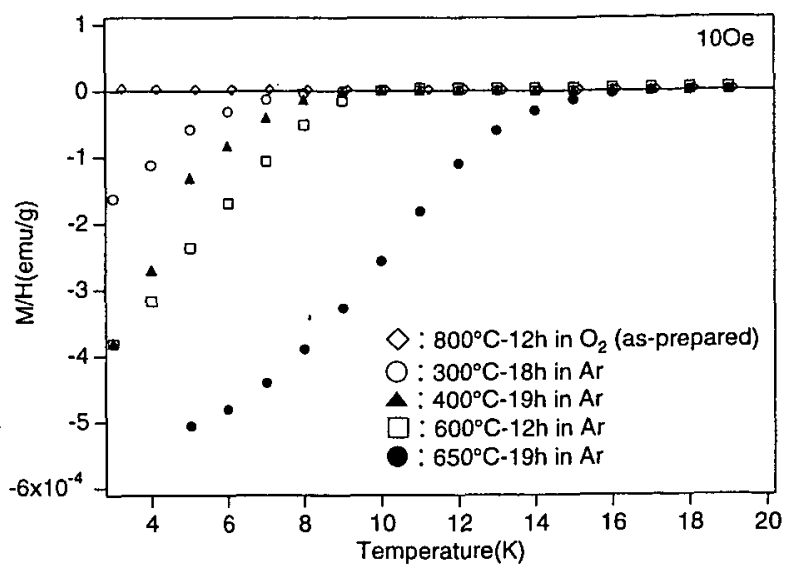

Fig.10 Temperature dependence of susceptibility for $\mathrm{Bi}_{2} \mathrm{Sr}_{2} \mathrm{CuO}_{\delta}$ after the annealing at various temperature in $\mathrm{Ar}$.

武田保雄先生に深く感謝いたします。

\section{文献}

1) Y.Ikeda, Z.Hiroi, H.Ito, S.Shimomura, M.Takano and Y.Bando: "Bi, Pb-Sr-Cu-O SYSTEM INCLUDING A MODULATIONFREE SUPERCONDUCTOR", Physica C, 165(1989)189-198.

2) Y.Ikeda, H.Ito, S.Shimomura, Y.Oue, K.Inaba, Z.Hiroi and M.Takano: "PHASES AND THEIR RELATIONS IN THE BiSr-Cu-O SYSTEM", Physica C, 159(1989)93-104.

3) J.A.Saggio, K.Sujata, J.Hahn, S.J.Hwu, K.Poeppelmeier and T.O. Mason: "Partial Bi-Sr-Cu-O Subsolidus Diagram at $800^{\circ} \mathrm{C}$ with and without Lithium Carbonate", J.Amer. Ceram. Soc., 72(1989) 849-853.

4) R.S.Roth, C.J.Rawn, B.P.Burton and F.Beech: "Phase Equilibria and Crystal Chemistry in Portions of the System SrO-CaO- $\mathrm{Bi}_{2} \mathrm{O}_{3}$ $\mathrm{CuO}$, Part II-The System SrO- $\mathrm{Bi}_{2} \mathrm{O}_{3}$-CuO", J. Res. Natl. Inst. Stand. Technol., 95(1990)291-335.

5) M.T.Caldes, M.Hervieu, A.Fuertes and B.Raveau: "Structural Mechanisms in the Bismuth Strontium Cuprates: HREM Study of Domains and Boundaries in Tubular Phases", J. Solid State Chem., 98(1992)301-311.

6) L.F.Schneemeyer, S.A.Sunshine, R.M.Fleming, S.H.Glarum R.B.Van Dover, P.M.Marsh and J.V.Waszczak: "Bulk superconductivity in single $\mathrm{CuO}$ layer $\mathrm{Bi}-\mathrm{Sr}-\mathrm{Cu}-\mathrm{O}$ ceramics", Appl. Phys. Lett., 57(1990)2362-2364.

7) M.Kato, K.Yoshimura and K.Kosuge: "Over-doped metallic behaivor of $\mathrm{Bi}_{2} \mathrm{Sr}_{2} \mathrm{CuO}_{y}$ ", Physica C, 177(1991)52-56.

8) R.M.Fleming, S.A. Sunshine, L.F.Schneemeyer, R.B.Van Dover, R.J.Cava, P.M.Marsh, J.V.Waszczak, S.H.Glarum and S.M.Zahurak and F.J. Disalvo: "Stoichiometry and superconductivity in single layer $\mathrm{Bi}_{2+x} \mathrm{Sr}_{2-y} \mathrm{Cu}_{6 \pm \delta^{\circ}}$, Physica C, 173(1991)37-50. 